\title{
Frequency of Canalis Sinuosus and its Anatomic Variations in Cone Beam Computed Tomography Images
}

\author{
Frecuencia de Canalis Sinuosus y sus Variaciones Anatómicas \\ en Imágenes de Tomografía Computarizada de Haz Cónico
}

\author{
Gloria Patricia Baena-Caldas ${ }^{1}$; Heidy Lisset Rengifo-Miranda ${ }^{2}$; Adriana María \\ Herrera-Rubio ${ }^{3}$; Ximara Peckham ${ }^{4}$ \& Janneth Rocio Zúñiga ${ }^{5}$
}

\begin{abstract}
BAENA-CALDAS, G. P.; RENGIFO-MIRANDA, H. L.; HERRERA-RUBIO, A. M.; PECKHAM, X. \& ZÚÑIGA, J. R. Frequency of canalis sinuosus and its anatomic variations in cone beam computed tomography images. Int. J. Morphol., 37(3):852-857, 2019.

SUMMARY: The aim of this paper was to determine the frequency of Canalis Sinuosus (CS) and its anatomic variations. A total of 236 cone beam computed tomography (CBCT) images were studied. Characteristics of the canal such as its form, pathway and diameter were analyzed. The CS was clearly visualized in $100 \%$ of the images with variations in the canal observed in up to $46 \%$ of the cases. In $79 \%$ of the cases the variation was found to be bilateral. The most common variation was an increase in the diameter (> $1 \mathrm{~mm})$ of the CS. Considering that the anterior region of the middle third of the face is a common place for clinical interventions, this study supports the need to perform a thorough evaluation of the maxillary region prior to clinical interventions in order to prevent complications such as direct or indirect injury to the anterior superior alveolar neurovascular bundle contained within the CS.
\end{abstract}

KEY WORDS: Maxillary nerve; Maxilla; Anatomic Variation; Tomography.

\section{INTRODUCTION}

The Canalis Sinuosus (CS) is a bone canal in the maxilla that branches from the infraorbital canal and ends laterally to the anterior nasal spine. The CS is frequently overlooked in anatomical descriptions of the maxilla and it is a potential site of iatrogenic lesions involving the anterior superior alveolar neurovascular bundle. This canal begins its pathway as a bifurcation of the infraorbital conduit, follows a descending and medial path on the anterior wall of the maxilla to the lateral wall of the pyriform aperture. It descends encircling the lateral and inferior edges of the pyriform aperture and finishes laterally on the anterior nasal spine, in a foramen called septal foramen. Under normal conditions, the CS has a diameter less than $1 \mathrm{~mm}$, and a length of approximately $1.5 \mathrm{~cm}$ on the orbit floor, $2 \mathrm{~cm}$ long in its full path through the maxilla, and $2 \mathrm{~cm}$ in the inferolateral part of the piriform aperture, for a total length of $5.5 \mathrm{~cm}$ (de Oliveira-Santos et al., 2013; von Arx et al., 2013; Manhães Júnior et al., 2016).

The CS contains the anterior superior alveolar neurovascular bundle, which irrigates, drains and innervates the upper canine and incisor teeth, the gums and mucosa of the same teeth, the inferior nasal meatus, the anterior part of the maxillary sinus, and the bottom of the nasal septum (Jones, 1939). It must be highlighted that the anterior superior alveolar nerve (ASAN) is one of the branches originated from the infraorbital nerve before entering the homologous foramen (Joo et al., 2014). The anterior superior alveolar artery is a branch of the infraorbital artery, which comes from the maxillary artery; and the anterior superior alveolar vein is a tributary of the pterygoid plexus (Jones).

Among the anatomic variations found in the maxilla are those related to the CS, mainly regarding its diameter and length. It is considered an anatomic variation of the canal if it has a diameter larger than $1 \mathrm{~mm}$, an ending that differs from the anterior nasal spine, or divisions of the canal along its pathway (Shelly et al., 1999; Vâlcu et al., 2011; Neves et al., 2012; de Oliveira-Santos et al.; von Arx et al.; Torres et al., 2015).

\footnotetext{
${ }^{1}$ Assistant Professor, Department of Morphology, Health Sciences Division, Universidad del Valle, Cali, Colombia.

${ }^{2}$ Dentistry School Student, Dentistry School, Health Sciences Division, Universidad del Valle, Cali, Colombia.

${ }^{3}$ Associate Profesor, Dentistry School, Health Science Division, Universidad del Valle, Cali, Colombia.

${ }^{4}$ Visiting Professor, Science Division, Biology Department, Long Island University, Brooklyn, 1 University Plaza, Biology Department, $8^{\text {th }}$ Fl, Brooklyn, NY, 11201.

NY, United States

${ }^{5}$ Associate Profesor, Department of Morphology, Health Science Division, Universidad del Valle, Cali, Colombia.
} 
Considering that the anterior region of the middle third of the face is a common place for surgical procedures such as orthognathic surgeries, as well as placement of dental implants, knowing the prevalence of CS and its anatomic variations is relevant due to the possibility of direct or indirect injury to the anterior superior alveolar neurovascular bundle (Vâlcu et al.; de Oliveira-Santos et al.; Wanzeler et al., 2015). The aim of this study is to determine the prevalence of CS and its anatomic variations by analyzing cone beam computed tomography (CBCT) images.

\section{MATERIAL AND METHOD}

In this descriptive, observational, retrospective, cross-sectional study, 236 CBCT images of the maxilla were selected from the image database in an imaging center from Cali/Colombia. Exclusion criteria included images with poor technical quality and/or noise generated by metal dental restorations or implants. This work was endorsed by the Human Ethics Committee of the Universidad del Valle (Cali, Colombia). The images used in this study were requested for diagnosis and treatment planning.

Images were obtained with a Next Generation iCAT® device (Imaging Sciences Int., Hatfield, PA, USA), and were analyzed with the iCAT Vision software provided by the manufacturer. Images were analyzed following a standardized protocol. First, using multiplanar navigation (MPR), the volume was aligned in order to have the median line parallel to the vertical reference line in the coronal

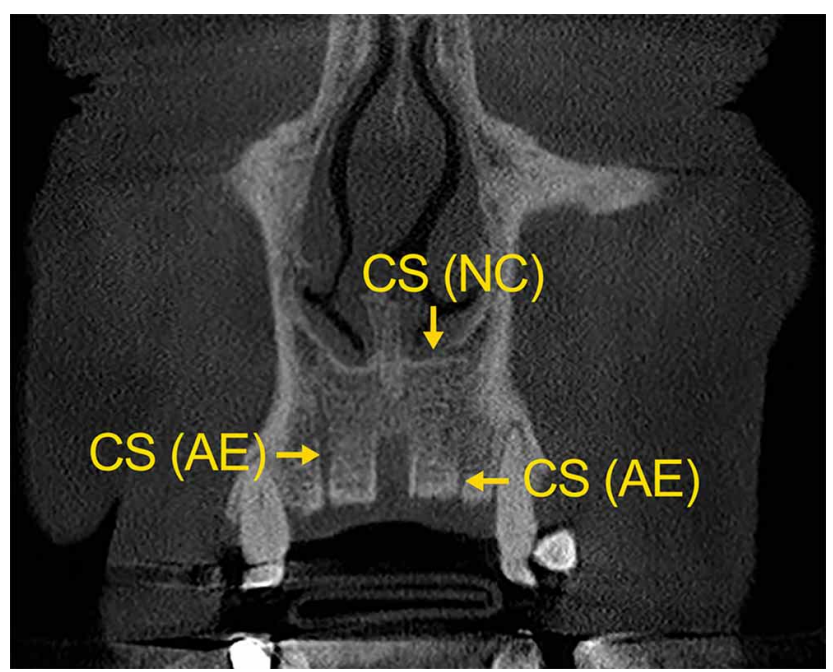

Fig. 1. Shows the non-corticalized segment of the left canalis sinuosus CS (NC) in the portion that goes to the anterior nasal spine segment. The bilateral aberrant extension of the canal CS (AE) towards the palate is also shown. and axial planes; and the palatal plane parallel to the horizontal reference line on the sagittal view. One of the researchers in collaboration with an Oral Maxillofacial radiologist with over 14 years of experience carefully evaluated the images.

The variables studied were: sex (male or female), age group (<20; 20-40; 41-60; > 60 years), canal presence and laterality of variation (right, left or bilateral). An anatomic variation of CS was considered only if there was presence of at least one of the parameters on Table I. The data analysis was performed using descriptive statistics, with the SPSS program, version 22.

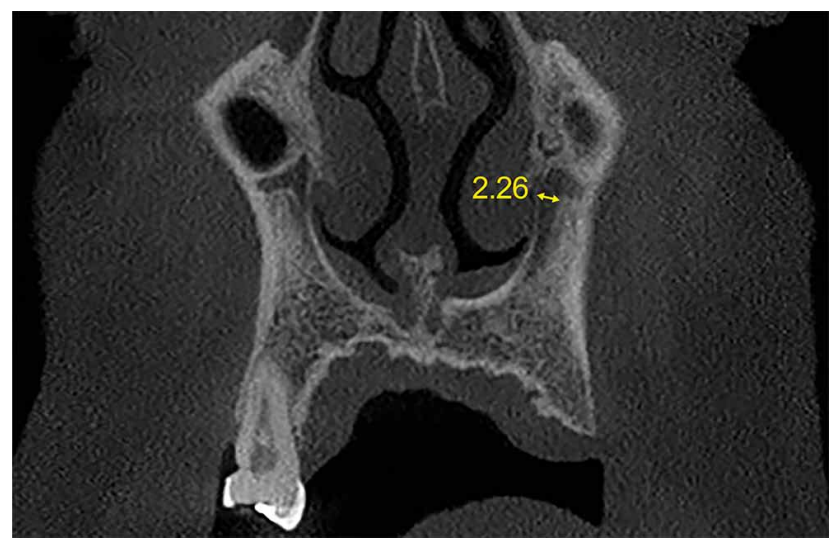

Fig. 2. Displays the left CS with a diameter > $1 \mathrm{~mm}$, which is considered as an anatomic variation.

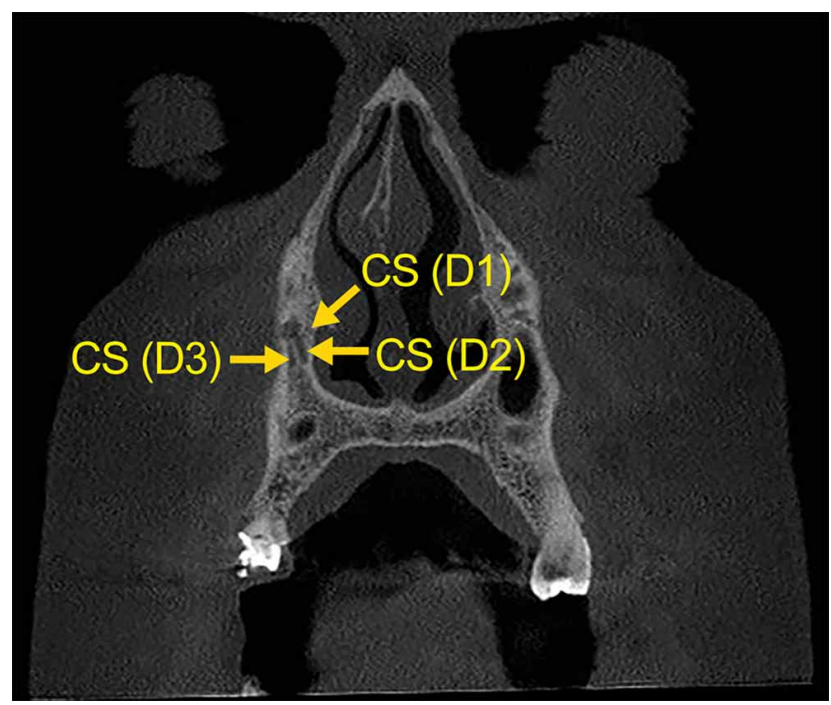

Fig. 3.The extension of the right CS towards the alveolar processes of the anterior teeth is highlighted. Division 1 of Canalis Sinuosus CS (D1) displays a normal medial trajectory towards the anterior nasal spine. Division 2 of Canalis Sinuosus CS (D2) follows a descending and vertical (aberrant) trajectory. CS (D3) is a terminal segment of the aberrant CS branch, located in the alveolar process of a superior anterior tooth. 


\section{RESULTS}

The 236 tomographic images, 130 of women $(55 \%)$ and 106 of men (45\%), were analyzed. The ages of the patients included in the sample ranged of 9 to 93 years, with an average age of 53 years. In the evaluated images, CS was identified in $100 \%$ of cases; $54 \%$ of the sample did not show anatomic variations of CS, while $46 \%$ had at least one canal variation. The most frequent anatomic variation was a canal diameter greater than $1 \mathrm{~mm}$. Anatomic variations were identified in $52(48 \%)$ female patients and $56(52 \%)$ male patients. The age range of the patients who presented variations fluctuated between 13 and 88 years, with an average of 53 years. Greater frequency in the variation was observed bilaterally in 85 cases (79\%); in 16 cases $(15 \%)$ on the right side and in 7 cases $(6 \%)$ on the left side (Table II).

The anatomic variations that were observed more frequently were an increase in the diameter of the canal, a multiple origin, division and aberrant extensions of the CS (Table III).

Table I. Parameters for classifying variations of the CS.

\begin{tabular}{lll}
\hline Variation Type & Subtype & Definition \\
2. Form & $\begin{array}{l}\text { Cortical } \\
\text { Divisions } \\
\text { Notapplicable }\end{array}$ & $\begin{array}{l}\text { Absence of cortical in segments of the canal pathway (Fig. 1). } \\
\text { Presence of bifurcations or trifurcations of the c anal along its route. } \\
\text { Canal diameter greater than 1 mm in all or a segment of its pathway (Fig. 2). }\end{array}$ \\
3. Pathway & $\begin{array}{l}\text { Extension up to } \\
\text { the palate }\end{array}$ & $\begin{array}{l}\text { The terminal canal segment (or one of its terminal segments) is projected more caudally } \\
\text { toward the anterior nasal spine until the anterior palate. Sometimes it gives rise to accessory } \\
\text { foramina on the palate (Fig. 1). }\end{array}$ \\
& $\begin{array}{l}\text { Extension to the } \\
\text { alveolar processes }\end{array}$ & $\begin{array}{l}\text { The terminal segment of the canal (or one of its terminal segments) ends its pathway at the } \\
\text { alveolar processes of the upper front teeth (Fig. 3). }\end{array}$ \\
\hline
\end{tabular}

Table II. Distribution of statistical variables. Presence of variation and age group, according to gender and laterality.

\begin{tabular}{|c|c|c|c|c|c|c|c|c|c|}
\hline \multirow{2}{*}{ Variable } & & \multicolumn{3}{|c|}{ Women $(n=130)$} & \multicolumn{3}{|c|}{ Men $(n=106)$} & \multirow{2}{*}{ Total } & \multirow{2}{*}{$\%$} \\
\hline & & Right & Left & Bilateral & Right & Left & Bilateral & & \\
\hline \multirow[t]{3}{*}{ Variation } & & 8 & 5 & 39 & 8 & 2 & 46 & 108 & 46 \\
\hline & 9 to 17 & 0 & 0 & 3 & 0 & 0 & 1 & 4 & 4 \\
\hline & 18 to 30 & 2 & 2 & 2 & 0 & 0 & 6 & 12 & 11 \\
\hline \multirow[t]{3}{*}{ Age group } & 31 to 50 & 1 & 0 & 10 & 1 & 0 & 12 & 24 & 22 \\
\hline & 51 to 70 & 4 & 0 & 21 & 5 & 0 & 22 & 52 & 48 \\
\hline & 71 or more & 1 & 3 & 3 & 2 & 2 & 5 & 16 & 15 \\
\hline
\end{tabular}

Table III. Observed anatomic variations of CS by segments. The initial segment refers to the region of the CS where it branches out from the infraorbitary duct. The intermediate segment is the portion in between the initial and final segment, located on the anterior part of the maxilla. The final segment is the last portion of CS.

\begin{tabular}{llc}
\hline S egment & \multicolumn{1}{c}{ Variations } & Frequency (\% \\
\hline $\begin{array}{l}\text { Initial } \\
\text { Intermediate }\end{array}$ & $\begin{array}{l}\text { Division of the infraorbitary duct in two places } \\
\text { Enlarged diameter }\end{array}$ & 6.99 \\
Final & $\begin{array}{l}\text { Aberrant extensions of the canal towards the palate or } \\
\text { towards the alveolar processes of the anterior superior teeth }\end{array}$ & 19.28
\end{tabular}

\section{DISCUSSION}

Several studies have previously found an elevated prevalence of CS. Wanzeler et al. observed a prevalence of $88 \%$ in a Brazilian population while Olenczak et al. (2015) found a prevalence of $100 \%$ in a sample of the US population, which is comparable to our findings. It is important to note that Wanzeler et $a l$. found no statistically significant difference between gender and laterality for the canal, while Olenczak et al. did not evaluate the gender or other sociodemographic variables. 
The values of prevalence of anatomic variations for CS varies considerably among the different reports (Table IV). One of the reasons why these differences occur is the methodology used by the authors. The studies by de Oliveira-Santos et al., von Arx et al. and Sekerci et al. (2015), focused on evaluating the prevalence of foramina and/or accessory canals in the anterior region of the maxilla exclusively. By contrast our study was not limited to a specific segment but rather a thorough evaluation of the entire canal was performed.

The study by de Oliveira-Santos et al., performed in Belgium, reported a prevalence of $7.86 \%$ of variations for CS, which manifested as a direct extension of the canal toward the front palate. In Switzerland, von Arx et al. reported a prevalence of $56.7 \%$ of accessory canals on the anterior region of the maxilla associated with variations of CS. A prevalence of $1.63 \%$ was reported by Sekerci et al. in a pediatric population study conducted in Turkey.

The observed accessory bone canals in the maxilla were direct extensions of CS. Wanzeler et al. studied the entire pathway of the CS and the frequency at which anatomic variations of the CS occurred could be established based on the description of canals coursing toward the palate or toward the lip region. However, no criteria to differentiate between normal and canal variations were established. In addition, they also noted the location of the terminal segment of CS and made measurements of the diameter of the canal at two points: where it branches from the infraorbital canal, and where it ends. In their work, $12.58 \%$ of the evaluated canals extend to the palate, corresponding to anatomic variations according to the criteria of this study. Furthermore, the aberrant location of the terminal portion of the canal -that is, at the apex of the teeth or near the apex, in the maxillary sinus, or the alveolar ridges- was observed in $40.58 \%$ of the images; this percentage is comparable to the $46 \%$ of CS variations reported in this study, including aberrant ending of the terminal portion of the canal, which differs from the septal foramen.

Regarding the associations between sex, age and presence of anatomic variations, de Oliveira-Santos et al. and von Arx et al. report no statistically significant differences among age groups or gender. In contrast, Sekerci et al. found a gender difference, with anatomic variations being more common in women than men, in contrast to our findings. On the other hand, Sekerci et al. found a steady increase of anatomic variations with age, although their study population was exclusively pediatric. We observed in our broad population range (9 to 93 years) a steady increase of anatomic variations that was proportional with age,although there was a decline after age 71 .

Furthermore, von Arx et al. found aberrant extensions of CS more frequently in the left side. In contrast, de Oliveira-Santos et al. observed bilateral accessory foramen in the palate, similar to what is reported in the present study, in which the anatomic variations for CS appear predominantly bilaterally.

A lack of knowledge of the existence of CS and its possible anatomic variations can affect the establishment of accurate diagnoses, and therefore appropriate treatments.

Table IV. Analysis of data in publications about canalis sinuosus.

\begin{tabular}{|c|c|c|c|c|c|}
\hline Author & Year & Population & $\begin{array}{l}\text { Sample } \\
\text { size }\end{array}$ & $\begin{array}{l}\text { Type of } \\
\text { simple }\end{array}$ & Study objective \\
\hline $\begin{array}{l}\text { de Oliveira- } \\
\text { Santos et al. }\end{array}$ & 2013 & Brazil & 178 & $\mathrm{CBCT}$ & $\begin{array}{l}\text { Presence of foramina and accessory canals in the anterior } \\
\text { region of the palate, some of which }(7.86 \%) \text { correspond to } \\
\text { extensions of CS. }\end{array}$ \\
\hline Von Arx et al. & 2013 & Switzerland & 176 & CBCT & $\begin{array}{l}\text { Presence of accessory canals in the anterior region of the } \\
\text { maxilla, some of which }(56.7 \%) \text { correspond to extensions } \\
\text { of CS. }\end{array}$ \\
\hline Manhães et al. & 2016 & Brazil & 500 & $\mathrm{CBCT}$ & $\begin{array}{l}\text { Presence of CS ( } 36.2 \%) \text {, laterality and distance to adjacent } \\
\text { anatomic structures (terminal segment). }\end{array}$ \\
\hline Machado et al. & 2016 & Brazil & 1000 & CBCT & $\begin{array}{l}\text { Prevalence of ac cessory canals of CS, distance to adjacent } \\
\text { structures and relationship to demographic variables. }\end{array}$ \\
\hline Gurler et al. & 2017 & Turkey & 111 & $\mathrm{CBCT}$ & $\begin{array}{l}\text { Study of the pathway of CS. Morphometric measurements } \\
\text { from CS to adjacent impacted canines. }\end{array}$ \\
\hline $\begin{array}{l}\text { Baena et al. } \\
\text { (Current study) }\end{array}$ & 2019 & Colombia & 236 & $\mathrm{CBCT}$ & $\begin{array}{l}\text { Prevalence of C S }(100 \%) \text {, frequency of its anatomic } \\
\text { variations }(46 \%) \text {, variations by segments of CS and } \\
\text { relationship to demographic variables. }\end{array}$ \\
\hline
\end{tabular}


It is also associated with complications by direct or indirect injury to the anterior superior alveolar neurovascular bundle, such as intraoperative bleeding, changes in the overall sensitivity of the territory of ASAN, and difficulty in osseointegration of implants (Arruda et al., 2017). For example, Shelley et al. (1999) reported a case in which an abnormal extension of this canal was mistaken for a periapical lesion on an intraoral x-ray. Vâlcu et al. reported the anatomic variation of a canal in the hard palate that was interpreted as a possible aberrant fissure of the maxilla, but may have been an anatomic variation of the CS.

In addition, the CS must be considered during the preoperative evaluation of surgical procedures involving the midface, as in Le Fort I osteotomy, in which a controlled fracture is performed lowering the lower third of the maxilla (O'Regan \& Bharadwaj, 2007). During this procedure, the canal is cut, thus causing a direct injury to the anterior superior alveolar neurovascular bundle with possible complications such as bleeding and dysesthesia (Vâlcu et al.; de Oliveira-Santos et al.). Placement of dental implants in the anterior region of the maxilla without prior assessment of the position and the characteristics of the canal may lead to iatrogenesis because placement of an implant inside the canal may be associated with pain and difficulty during osseointegration (Al-Khabbaz et al., 2007; Neves et al.; de Oliveira-Santos et al.; Wanzeler et al.). It is also important to be considered when performing anesthetic procedures and lifting flaps in the anterior region of the palate, because the aberrant canal extensions toward the palate provide innervation to areas that do not usually depend on the anterior superior alveolar nerve; likewise, its neurovascular content can be sectioned when lifting the flap (Vâlcu et al.; Neves et al.). These situations plus the high prevalence of $\mathrm{CS}$ and its high frequency of anatomic variations emphasize the importance for health providers to be aware and correctly identify the possible variations of CS.

We found that CS could be identified in all the CBCT images evaluated. In a large number of our study population $(46 \%)$ there was evidence of at least one anatomic variation, being the most frequent a CS diameter greater than $1 \mathrm{~mm}$. Considering the implications for clinical practice and the low number of publications about this anatomical structure (Gurler et al., 2017), the authors of this study recommend additional studies to further investigate the morphometric characteristics such as diameter, canal path and types of anatomic variations and also recommend a thorough study of the maxillary region to rule out the possibility of variations as part of the preoperative medical evaluation in order to prevent complications involving the anterior superior alveolar neurovascular bundle contained within the CS.

\section{ACKNOWLEDGEMENTS}

This study was presented at the XL National Conference of Oral and Maxillofacial Surgery on February 2016 in Cartagena, Colombia where it was awarded as the Best Free Topic Presentation. We want to thank the AmadeuScan3D Radiology Center for facilitating the evaluation of the images that were used for this study, Thanks to Fabian Cabrera for processing and editing the images.

BAENA-CALDAS, G. P.; RENGIFO-MIRANDA, H. L.; HERRERA-RUBIO, A. M.; PECKHAM, X. \& ZÚÑIGA, J. R. Frecuencia de Canalis Sinuosus y sus variaciones anatómicas en imágenes de tomografía computarizada de haz cónico. Int. J. Morphol., 37(3):852-857, 2019.

RESUMEN: El objetivo de este trabajo fue determinar la frecuencia de Canalis Sinuosus (CS) y sus variaciones anatómicas. Se estudiaron un total de 236 imágenes de tomografía computarizada de haz cónico (CBCT). Se analizaron las características del canal, como su forma, vía y diámetro. El CS se visualizó claramente en el $100 \%$ de las imágenes, observándose variaciones en el canal en hasta el $46 \%$ de los casos. En el $79 \%$ de los casos la variación fue bilateral. La variación más común fue un aumento en el diámetro (> $1 \mathrm{~mm}$ ) de la CS. Teniendo en cuenta que la región anterior del tercio medio de la cara es un lugar común para las intervenciones clínicas, este estudio apoya la necesidad de realizar una evaluación exhaustiva de la región maxilar antes de las intervenciones clínicas para prevenir complicaciones como lesiones directas o indirectas a el haz neurovascular alveolar superior anterior contenido dentro de la CS.

PALABRAS CLAVE: Nervio maxilar; Maxilar; Variación anatómica; Tomografía.

\section{REFERENCES}

Al-Khabbaz, A. K.; Griffin, T. J. \& Al-Shammari, K. F. Assessment of pain associated with the surgical placement of dental implants. J. Periodontol., 78(2):239-46, 2007.

Arruda, J. A.; Silva, P.; Silva, L.; Álvares, P.; Silva, L.; Zavanelli, R.; Rodrigues, C.; Gerbi, M.; Sobral, A. P. \& Silveira, M. Dental implant in the Canalis Sinuosus: a case report and review of the literature. Case Rep. Dent., 2017:4819123, 2017.

de Oliveira-Santos, C.; Rubira-Bullen, I. R.; Monteiro, S. A.; León, J. E. \& Jacobs, R. Neurovascular anatomical variations in the anterior palate observed on CBCT images. Clin. Oral Implants Res., 24(9):1044-8, 2013.

Gurler, G.; Delilbasi, C.; Ogut, E. E.; Aydin, K. \& Sakul, U. Evaluation of the morphology of the Canalis Sinuosus using conebeam computed tomography in patients with maxillary impacted canines. Imaging Sci. Dent., 47(2):69-74, 2017.

Jones, F. W. The anterior superior alveolar nerve and vessels. J. Anat., 73(Pt. 4):583-91, 1939.

Joo, W.; Yoshioka, F.; Funaki, T.; Mizokami, K. \& Rhoton, A. L. Jr. Microsurgical anatomy of the trigeminal nerve. Clin. Anat., 27(1):61-88, 2014. 
Manhães Júnior, L.R .; Villaça-Carvalho, M. F.; Moraes, M. E.; Lopes, S. L.; Silva, M. B. \& Junqueira, J. L. Location and classification of Canalis Sinuosus for cone beam computed tomography: avoiding misdiagnosis. Braz. Oral Res., 30(1):e49, 2016.

Neves, F. S.; Crusoé-Souza, M.; Franco, L. C.; Caria, P. H.; BonfimAlmeida, P. \& Crusoé-Rebello, I. Canalis Sinuosus: a rare anatomical variation. Surg. Radiol. Anat., 34(6):563-6, 2012.

O'Regan, B. \& Bharadwaj, G. Prospective study of the incidence of serious posterior maxillary haemorrhage during a tuberosity osteotomy in low level Le Fort I operations. Br. J. Oral Maxillofac. Surg., 45(7):538-42, 2007.

Olenczak, J. B.; Hui-Chou, H. G.; Aguila, D. J. 3rd.; Shaeffer, C. A.; Dellon, A. L. \& Manson, P. N. Posttraumatic midface pain: clinical significance of the anterior superior alveolar nerve and Canalis Sinuosus. Ann. Plast. Surg., 75(5):543-7, 2015.

Sekerci, A. E.; Cantekin, K. \& Aydinbelge, M. Cone beam computed tomographic analysis of neurovascular anatomical variations other than the nasopalatine canal in the anterior maxilla in a pediatric population. Surg. Radiol. Anat., 37(2):181-6, 2015.

Shelley, A. M.; Rushton, V. E. \& Horner, K. Canalis Sinuosus mimicking a periapical inflammatory lesion. Br. Dent. J., 186(8):378-9, 1999.

Torres, M. G.; de Faro Valverde, L.; Vidal, M. T. \& Crusoé-Rebello, I. M. Branch of the In Vitro: a rare anatomical variation--a case report. Surg. Radiol. Anat., 37(7):879-81, 2015.

Vâlcu, M.; Rusu, M. C.; Sendroiu, V. M. \& Didilescu, A. C. The lateral incisive canals of the adult hard palate - aberrant anatomy of a minor form of clefting? Rom. J. Morphol. Embryol., 52(3):947-9, 2011.

von Arx, T.; Lozanoff, S.; Sendi, P. \& Bornstein, M. Assessment of bone channels other than the nasopalatine canal in the anterior maxilla using limited cone beam computed tomography. Surg. Radiol. Anat., 35(9):783-90, 2013.

Wanzeler, A. M.; Marinho, C. G.; Alves Junior, S. M.; Manzi, F. R. $\&$ Tuji, F. M. Anatomical study of the Canalis Sinuosus in 100 cone beam computed tomography examinations. Oral Maxillofac. Surg., 19(1):49-53, 2015.

\author{
Corresponding autor: \\ Gloria Patricia Baena-Caldas \\ Department of Morphology \\ Health Sciences Division \\ Universidad del Valle \\ Calle 4B \#36-00, Edificio 116 \\ Cali \\ COLOMBIA
}

Email: gloria.baena@correounivalle.edu.co

Received: 10-01-2019

Accepted: 05-04-2019 